\title{
Hayat Bilgisi ve Sosyal Bilgiler Ders Kitaplarına Yönelik 2005- 2018 Yilları Arasındaki Makalelerin İncelenmesi ${ }^{1}$
}

\author{
(iD) Nur ÜTKÜR \\ İstanbul Üniversitesi-Cerrahpaşa, Hasan Ali Yücel Fakültesi, Temel Eğitim Bölümü \\ nur.utkur@istanbul.edu.tr
}

Gönderilme Tarihi: 10/06/2018

Kabul Tarihi: $26 / 11 / 2018$

Yayınlanma Tarihi: 30/11/2018

DOI: $10.30855 /$ gjes.2018.04.03.001

\begin{tabular}{|c|c|}
\hline Makale Bilgileri & ÖZET \\
\hline $\begin{array}{l}\text { Anahtar } \\
\text { Kelimeler: } \\
\text { Hayat bilgisi, } \\
\text { Sosyal bilgiler, } \\
\text { Ders kitapları }\end{array}$ & 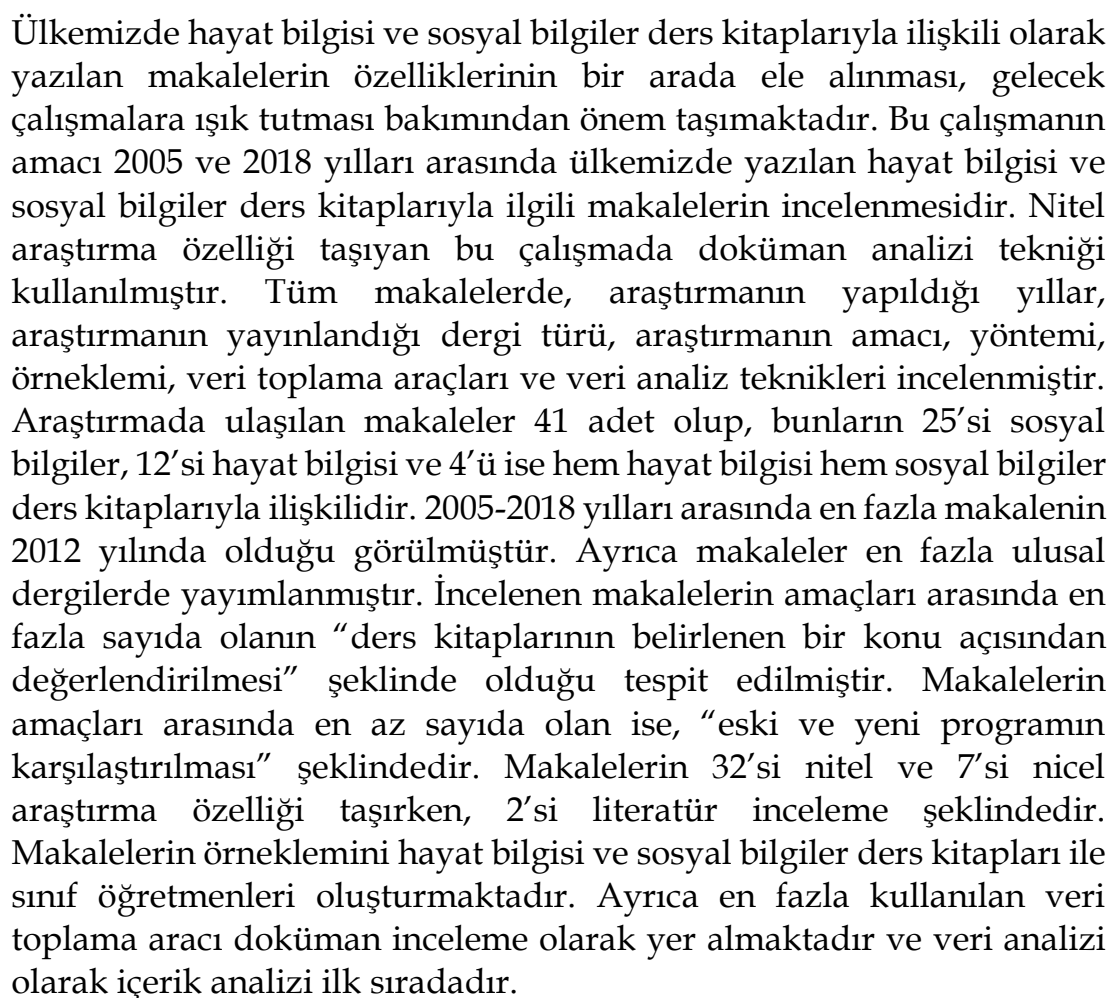 \\
\hline
\end{tabular}

${ }^{1}$ Bu çalışma Ders Kitapları Uluslararası Sempozyumu'nda (12-14 Nisan 2018) sunulan sözlü bildirinin genişletilmiş halidir.

Ütkür, N. (2018). Hayat bilgisi ve sosyal bilgiler ders kitaplarına yönelik 2005-2018 yılları arasındaki makalelerin incelenmesi. Gazi Eğitim Bilimleri Dergisi, 4(3), 1-11. https://dx.doi.org/10.30855/gjes.2018.04.03.001.

Dergi Web Sayfast: http://dergipark.gov.tr/gebd 


\section{An Examination of the Articles on Life Studies and Social Studies Textbooks between 2005-2018 Years}

\begin{tabular}{ll}
\hline Article Info & ABSTRACT \\
\hline Keywords: & $\begin{array}{l}\text { Taking together the features of the articles written in relation to life } \\
\text { Life studies, } \\
\text { Social studies, } \\
\text { Textbooks }\end{array}$ \\
terms of shedding light on future studies. The aim of this study is to \\
examine the articles on life studies and social studies textbooks written \\
in our country between 2005 and 2018. Document analysis technique is \\
used in this study which has qualitative research feature. In all articles, \\
the years in which the research was conducted, the journal type \\
published, the purpose of the research, methodology, sampling, data \\
collection tools and data analysis techniques are examined. There are 41 \\
articles in the research, 25 of which are related to social studies, 12 are \\
related to life studies and 4 are related to both life studies and social \\
studies textbooks. Between the years 2005-2018, the most articles are in \\
2012. These articles have also been published in national journals. \\
Among the aims of the examined articles, it was determined that the \\
largest number was the "evaluation of textbooks from a specified point \\
of view". Among the purposes of the articles, the least number is the \\
"comparison of old and new programs". While 32 of the articles are \\
qualitative research and 7 are of quantitative research, 2 is the literature \\
review. Samples of the articles are life studies and social studies \\
textbooks and classroom teachers. In addition, the most commonly used \\
data collection tool is document review and content analysis is the first \\
place in data analysis.
\end{tabular}

\section{Gİisiş}

Ülkemizde hayat bilgisi ve sosyal bilgiler dersleri ilkokul ve ortaokulda öğrencilerin yaşamlarından unsurlar barındırması ve bunları sınıf ortamında yansıtması özellikleriyle bilinmektedir. Bu nedenle özellikle ilkokul ve ortaokul öğrencilerinin yaşantılarında diğer dersler gibi önemli rol oynamaktadırlar. Hayat bilgisi dersi ilkokulda 1, 2 ve 3. sinıfta okutulmaktayken, sosyal bilgiler dersi ilkokulda 4 . sinıf ve ortaokulda 5, 6 ve 7. sinıf seviyesinde okutulmaktadır (Milli Eğitim Bakanlığı, 2018).

Okullarda okutulan ders kitaplarının öğretmenler ve öğrenciler için ders işleme sürecinde ne derece önemli olduğu da bilinmektedir. Ders kitapları, okullarda öğretmenlerin en önemli rehberleri olup dersin işlenişini önemli ölçüde etkileyen ders materyallerindendir. Bu nedenle bunların sınıf ortamlarında kullanılış şekilleri ve incelenmesiyle ilgili çalışmaların bütüncül bir bakış açısıyla ele alınması önem taşımaktadır.

Ülkemizde hayat bilgisi ve sosyal bilgiler ders kitaplarılya ilgili yapılan birçok çalışma yer almaktadır (Akcan, 2005; Akman ve Bastık, 2016; Aksoy ve Sönmez, 2012; Alaca, 2017; Aladağ ve Karaman, 2018; Alkış, 2005; Alpan, 2004; Aykaç, 2012; Baltacı ve Uysal, 2012; Berkant ve Atmaca, 2013; Çoban ve Temir, 2018; Doğan ve Tuğ, 2017; Erol ve Kıroğlu, 2012; Gezer ve İlhan, 2015; Gözütok, Taş, Rüzgar, Akçatepe ve Yetkiner, 2015; Gülersoy, 2013; Gülüm ve Çeltik, 2014; Güven, 2010; Güzel-Candan ve Ergen, 2014; İncekara ve Karatepe, 2010; Kabapınar, 2002; Kabapınar, 2007; Kabapınar ve Akbal, 2010; Kabapınar ve Özkan, 2012; Karabacak ve Turan, 2017; Karaca ve Ocak, 2011; Karaman-Kepenekci ve Ökdem, 2013; Kaya, Topçu ve Kop, 2014; Kaymakcı ve Er, 2013; Keskin ve Yaman, 2014; Mentiş-Taş, 2007; Nalçacı, 2011; Öztürk, 2011; Öztürk ve Özkan, 
2018; Pamuk ve Pamuk, 2016; Sever ve Koçoğlu, 2013; Şahin, 2012; Tay, 2005; Tel, 2014; Turan, Şahan, Işık, Özdemir, Uysal ve Yılmaz, 2017; Ünal ve Ilgaz, 2005; Ünal ve Ünal, 2012). Hayat bilgisi ve sosyal bilgiler ders kitaplarıyla ilişkili olarak ortaya konulan bu çalışmaların özelliklerinin bir arada ele alınması, gelecek çalışmalara ışık tutması ve bütünü görebilmek bakımından önem taşımaktadır.

Ulusal literatür incelendiğinde hayat bilgisi ders kitaplarıyla yapılan çalışmaların içerik analizine yönelik bir çalışmaya rastlanmışken (Güven ve Ayyayla-Püsküllü, 2017), birbirini hem sinuf hem de konular olarak tamamlayan iki ders olan hayat bilgisi ve sosyal bilgiler ders kitaplarıyla ilgili yapılan çalışmaların içerik analizine yönelik herhangi bir çalışmaya rastlanılmamıştır. Bu nedenle bu çalışmanın literatüre bir katkısının olacağı düşünülmektedir.

Bu doğrultuda bu çalışmanın amacı 2005 ve 2018 yılları arasında ülkemizde yazılan hayat bilgisi ve sosyal bilgiler ders kitaplarıyla ilgili makalelerin incelenmesi, bütüncül bir bakış açısıyla ele alınmasıdır. Bu amaçla aşağıdaki araştırma sorularına cevap aranmıştır.

1. İncelenen makalelerin yılları ve yayımlandığı dergi türleri nelerdir?

2. İncelenen makalelerde hangi dersler yer almaktadır?

3. İncelenen makalelerin amaçları nasıl farklılaşmıştır?

4. İncelenen makalelerin çalışma grubu/örneklem özellikleri nelerdir?

5. İncelenen makalelerde hangi araştırma yöntemleri ve veri toplama araçları kullanılmıştır?

6. İncelenen makalelerde hangi veri analizi türleri kullanılmıştır?

\section{YÖNTEM}

Bu çalışmada nitel araştırma özelliği taşımaktadır ve yöntem olarak doküman incelemesi kullanılmıştır (Yıldırım ve Şimşek, 2013).

\section{Örneklem}

Bu çalışmada ülkemizde 2005 ve 2018 yılları arasında yazılan hayat bilgisi ve sosyal bilgiler ders kitaplarıyla ilgili ulaşılabilen 41 adet makale incelenmiştir. Bu makalelere ulaşabilmek için öncelikle hayat bilgisi ve sosyal bilgiler ile ilgili yapılmış çalışmalar belirlenmiş, aralarından "ders kitapları" ile ilgili olanlar tespit edilmiştir. Böylece çeşitli indekslerde olan, ulusal ve uluslararası toplam 41 dergide yer alan makaleler ele alınmıştır.

\section{Veri Toplama Araçları}

Ulaşılan makalelerin tümü doküman incelemesi yöntemi ile incelenmiştir. Bu inceleme yapılırken "makalelerin yayımlandığı dergi türü, yayımlandığı yıl, makalelerde yer alan ders türleri, makalelerde yer alan konuların özellikleri, çalışma grubu ve örneklem özellikleri, makalelerin yöntemi, veri toplama araçları ve veri analiz türleri"nin yer aldığı bir form oluşturulmuştur. Bu formda yer alan maddelere yönelik 8 öğretim elemanının görüusü alınmıştır. Formda yer alan maddelerin kapsam geçerlik indeksleri Lawshe (1975) tekniği kullanılarak hesaplanmıştır. Buna göre Lawshe (1975) tekniği uygulanırken, 8 uzmanın görüşü alındığında kapsam geçerlik indeksinin minimum 0,78 olması gerekmektedir (akt. Yurdugül, 2005). Bu formdaki maddelerin kapsam geçerlik indeksleri 0,98 çıtığından maddelerin geçerli olduğu sonucuna ulaşılmıştır. 


\section{Verilerin Analizi}

Çalışmada ulaşılan verilerin analizinde içerik analizi kullanılmıştır. İçerik analizinde oluşturulan verilerin kodlanmasında alanda uzman iki öğretim elemanından yardım alınmıştır. Araştırmacı tarafından incelenen makaleler, diğer öğretim elemanları tarafından oluşturulan forma göre tekrar incelenmiştir. Öğretim elemanları ve araştırmacının kodlamaları birbirleriyle karşılaştırılmıştır. Bu karşılaştırma için Miles ve Huberman'ın (1994) kodlayıcı güvenirlik formülü kullanılmıştır. Miles ve Huberman'a (1994) göre bu değer 0,80'in üzerinde bulunduğunda analiz güvenilir sayılmaktadır. Veri toplama araçlarının analizinde farklı öğretim elemanlarının kodlayıcı güvenirlik katsayı değerlerine Tablo 1'de yer verilmiştir.

Tablo 1. Veri Toplama Araçlarının Güvenirlik Değerleri

\begin{tabular}{lccc}
\hline Veri toplama aracı & $\begin{array}{c}\text { Güvenirlik } \\
\text { katsayısı } \\
(1 . \text { Kişi) }\end{array}$ & $\begin{array}{c}\text { Güvenirlik } \\
\text { katsayısı } \\
(2 . \text { Kişi) }\end{array}$ & $\begin{array}{c}\text { Güvenirlik } \\
\text { katsayısı } \\
\text { (Ortalama) }\end{array}$ \\
\hline Doküman inceleme & 0,98 & 0,99 & 0,99 \\
\hline
\end{tabular}

Tablo 1'de yer alan veriler doğrultusunda araştırmacı ile 1. ve 2. öğretim elemanlarının güvenirlik katsayısı ortalamasının 0.99 çıkması dolayısıyla yapılan analizlerin güvenilir sayılabileceği sonucuna ulaşılmıştır.

\section{BULGULAR}

\section{Makalelerin yılları ve yayımlandıkları dergi türleri}

Hayat bilgisi ve sosyal bilgiler ders kitaplarıla ilgili olarak incelenen makalelerin hangi dergi türlerinde ve hangi yıllarda yayımladığıyla ilgili verilere Tablo 2 ve Tablo 3 'te yer verilmiştir.

Tablo 2. Dergi Türleri

\begin{tabular}{cc}
\hline Dergi türü & Sayı (f) \\
\hline Ulusal dergi & 27 \\
Uluslararası dergi & 14 \\
\hline Toplam & $\mathbf{4 1}$ \\
\hline
\end{tabular}

Tablo 2'de görüldüğü üzere incelenen toplam 41 makalenin 27'si ulusal dergilerde yayımlanırken, $14^{\prime}$ ü uluslararası dergilerde yayımlanmıştır. 
Tablo 3. Makalelerin Yayımlanma Yılları

\begin{tabular}{cc}
\hline Y1llar & Say1 (f) \\
\hline 2005 & 4 \\
2007 & 3 \\
2010 & 3 \\
2011 & 3 \\
2012 & 7 \\
2013 & 5 \\
2014 & 5 \\
2015 & 2 \\
2016 & 2 \\
2017 & 4 \\
2018 & 3 \\
\hline Toplam & $\mathbf{4 1}$ \\
\hline
\end{tabular}

Tablo 3'e göre, incelenen makalelerin en fazla 2012 yılında yayımlandığı, bunu 2013 ve 2014 yıllarının takip ettiği görülmektedir. Ayrıca en az sayıda makale 2015 ve 2016 yıllarında yayımlanmıştır.

\section{Makalelerde yer alan dersler}

İncelenen makalelerde yer alan ders türlerine Tablo 4 'te yer verilmiştir.

Tablo 4. Makalelerde Yer Alan Ders Türleri

\begin{tabular}{cc}
\hline Ders Türü & Sayı (f) \\
\hline Sosyal Bilgiler & 25 \\
Hayat Bilgisi & 12 \\
Sosyal Bilgiler ve Hayat Bilgisi & 4 \\
\hline Toplam & $\mathbf{4 1}$ \\
\hline
\end{tabular}

Tablo 4'te de görüldüğü üzere toplam 41 makalenin 25'inde sosyal bilgiler ders kitapları yer almaktaken, 12'sinde hayat bilgisi ders kitapları yer almaktadır. Ayrıca 4 makalede ise hem sosyal bilgiler hem de hayat bilgisi kitapları incelenmiştir.

\section{Makalelerin amaçları}

İncenen makalelerde yer alan konuların genel özelliklerine Tablo 5 'te yer verilmiştir.

Tablo 5. Makalelerde Yer Alan Konuların Özellikleri

\begin{tabular}{lc}
\hline Konular & Sayı (f) \\
\hline Çalışmaların belirlenen bir konu çerçevesinde değerlendirilmesi & 25 \\
Ders kitaplarına yönelik öğretmen görüşleri & 7 \\
Görsel ve biçimsel özelliklerin incelenmesi & 6 \\
Eski ve yeni program karşılaştırması & 2 \\
Ders kitapları üzerine genel değerlendirme & 1 \\
\hline Toplam & $\mathbf{4 1}$ \\
\hline
\end{tabular}


Tablo 5 'te yer alan özellikler incelendiğinde makalelerin $25^{\prime}$ inde, çalışmaların belirlenen bir konu çerçevesinde değerlendirildiğinin tespit edildiği görülmüştür. Ayrıca çalışmaların 7 'sinde ders kitaplarına yönelik öğretmen görüşleri alınırken, 6'sında ders kitapları görsel ve biçimsel olarak incelenmiştir. Çalışmaların yalnız 2 'sinde eski ve yeni program değerlendirilmesi yapılırken, yalnız 1'inde ders kitapları üzerine genel değerlendirmeye yer verilmiştir.

\section{Makalelerin çalışma grubu/örneklem özellikleri}

Tablo 6'da incelenen makalelerde yer alan çalışma grubu ve örneklem özelliklerine yer verilmiştir.

Tablo 6. Çalışma Grubu/Örneklem Özellikleri

\begin{tabular}{|c|c|c|c|}
\hline Ana Temalar & Alt Temalar & Alt Temalar & Sayı (f) \\
\hline \multirow{10}{*}{ Ders Kitapları } & \multirow{3}{*}{ Hayat Bilgisi } & 1. Sinif & 8 \\
\hline & & 2. Sinif & 10 \\
\hline & & 3. Sinif & 11 \\
\hline & \multirow{4}{*}{ Sosyal Bilgiler } & 4. Sinif & 13 \\
\hline & & 5. Sinif & 14 \\
\hline & & 6. Sinif & 18 \\
\hline & & 7. Sinif & 18 \\
\hline & İnkılap Tarihi & 8. Sinif & 1 \\
\hline & \multirow{2}{*}{ Tarih } & 9. Sinif & 1 \\
\hline & & 10. Sinif & 1 \\
\hline \multirow{4}{*}{ Öğretmenler } & \multirow{4}{*}{ Sınıf Öğretmenleri } & 0-50 kişi & 2 \\
\hline & & 51-100 kişi & 4 \\
\hline & & 101-300 kişi & 3 \\
\hline & & 301 ve üzeri & 1 \\
\hline
\end{tabular}

Tablo 6'da görüldüğ ü üzere, incelenen makalelerin çalışma grubu ve örneklem özellikleri iki ana başlık altında ele alınmıştır. Yalnızca ders kitaplarının incelendiği çalışmalarda, 1, 2 ve 3. sinıf hayat bilgisi ders kitapları, 4, 5, 6 ve 7. sinıf sosyal bilgiler kitapları, 8. sinıf inkılap tarihi kitabı ile 9. ve 10. sınıf tarih kitapları örneklemi oluşturmuştur.

Sosyal bilgiler ders kitaplarıyla ilgili yapılan çalışmalardan birinde sosyal bilgilerle ilişkili olduğu düşünüldüğünden, 5, 6, 7. sınıf sosyal bilgiler kitapları yanı sıra 8. sınıf inkilap tarihi kitabına yer verildiği tespit edilmiştir. Ayrıca bir diğer çalışmada, yine sosyal bilgiler 6. ve 7. sınıf kitapları yanı sıra, 9. ve 10. sınıf tarih kitaplarının da incelendiği belirlenmiştir.

İncelenen tüm çalışmalar arasında en fazla sosyal bilgiler kitaplarının yer aldığı görülmektedir. Ayrıca ders kitaplarının incelenmesinin yanında, öğretmen görüşlerinin de alındığı çalışmalarda, sınıf öğretmenlerinin görüşleri alınmıştır. Bu öğretmenlerin sayı aralığının en fazla 51-100 aralığında olduğu tespit edilmiştir.

\section{Makalelerin araştırma yöntemleri ve veri toplama araçları}

İncelenen makalelerde kullanılan yöntemlere ilişkin verilere Tablo $7^{\prime}$ de yer verilmiştir.

Tablo 7. Makalelerin Yöntemi

\begin{tabular}{cc}
\hline Yöntemin Türü & Sayı (f) \\
\hline Nitel yöntem & 32 \\
Nicel yöntem & 7 \\
Literatür tarama & 2 \\
\hline Toplam & $\mathbf{4 1}$ \\
\hline
\end{tabular}


Tablo 7 incelendiğinde, makalelerin 32'sinde nitel yöntem yer alırken, 7'sinde nicel yöntemin yer aldığı tespit edilmiştir. Ayrıca yalnızca 2 makalede literatür tarama yapılarak ders kitaplarıyla genel bir inceleme yapılmıştır.

İncelenen makalelerde kullanılan veri toplama araçlarının yer aldığı verilere Tablo 8 'den ulaşılabilmektedir.

Tablo 8. Makalelerin Veri Toplama Araçları

\begin{tabular}{cc}
\hline Veri Toplama Araçları & Sayı (f) \\
\hline Doküman inceleme & 28 \\
Anket & 6 \\
Görüşme & 3 \\
Rubrik & 2 \\
Ölçek & 1 \\
Literatür tarama & 1 \\
\hline Toplam & $\mathbf{4 1}$ \\
\hline
\end{tabular}

Tablo 8'e göre, makalelerin büyük çoğunluğunda (28 adet) doküman incelemenin veri toplama aracı olarak kullanıldığı tespit edilmiştir. Ayrıca kullanılan diğer veri toplama araçları 6 çalışmada anket, 3 çalışmada görüşme, 2 çalışmada rubrik ve yalnızca 1 çalışmada ölçektir. Çalışmalardan yalnızca 1'inde ise literatür tarama şeklinde ders kitapları üzerine genel bir değerlendirme yapıldığı belirlenmiştir.

\section{Makalelerin veri analizi türleri}

İncelenen makalelerde kullanılan veri analiz türlerine Tablo 9'da yer verilmiştir.

Tablo 9. Makalelerin Veri Analizi Türleri

\begin{tabular}{cc}
\hline Veri Analizi & Sayı (f) \\
\hline İçerik analizi & 21 \\
Betimsel analiz & 13 \\
Frekans ve yüzde hesaplama & 6 \\
Varyans analizi & 2 \\
t testi & 2 \\
\hline Toplam & $\mathbf{4 4}$ \\
\hline
\end{tabular}

Tablo 9'da yer alan veriler doğrultusunda toplam 44 veri analizi türünün 21'i içerik analiziyken, 13'ü betimsel analizdir. Ayrıca 6 çalışmada frekans ve yüzde hesaplamayla veriler analiz edilmişken, 2 'şer çalışmada varyans analizi ve $t$ testi kullanılmıştır.

Çalışmalardan birinde $\mathrm{t}$ testi ve varyans analizi birlikte kullanılmışken, bir diğerinde frekans ve yüzde hesaplama ile $t$ testi ve varyans analizi birlikte yer almıştır.

\section{SONUÇ, TARTIŞMA VE ÖNERILER}

Bu çalışmada 2005-2018 yılları arasında yayımlanmış hayat bilgisi ve sosyal bilgiler ders kitaplarıyla ilgili olan 41 adet makale incelenmiştir. Bu makalelerin $25^{\prime} \mathrm{i}$ sosyal bilgiler, 12 'i hayat bilgisi ve $4^{\prime} \ddot{u}$ ise hem hayat bilgisi hem sosyal bilgiler ders kitaplarıla ilişkilidir. Ayrıca bu makalelerin yayımlanma yılları arasında en fazla sayıda 2012 yılının olduğu, bunu 2013 ve 2014 yıllarının takip ettiği belirlenmiştir. En az çalışma ise, 2015 ve 2016 yıllarında yapılmıştır. Bu durum 2012' deki program değişikliği sonrasında ders kitaplarıyla ilgili yoğunluklu çalışmaların yapılmasına bağlanabilmektedir. 
Makalelerin uluslararası dergilere oranla daha fazla olarak ulusal dergilerde yayımlandığı tespit edilmiştir. Güven ve Ayyayla-Püsküllü'nün (2017) çalışmasında da ulusal dergiler olarak ulakbimde taranan dergilerin incelendiği görülmektedir.

Bu çalışmada incelenen makalelerin amaçları arasında en fazla sayıda "ders kitaplarının belirlenen bir konu açısından değerlendirilmesi" şeklinde olduğu tespit edilmiştir. Yapılan çalışmalarda tespit edilen unsur, ders kitaplarıyla ilgili araştıılmak istenen bir konu ele alınarak o konuya yönelik değerlendirmenin yapılması şeklindedir. En az sayıda olanlar ise, "eski ve yeni programın karşılaştırılması ve ders kitapları üzerine genel değerlendirme" olarak tespit edilmiştir.

Makalelerin örneklemini hayat bilgisi, sosyal bilgiler, tarih ve inkılap tarihi ders kitapları ile sınıf öğretmenleri oluşturmaktadır. Ders kitaplarından en fazla sayıda incelenen sosyal bilgiler ders kitaplarıyken, en az sayıda incelenen ise tarih ve inkılap tarihi ders kitaplarıdır. Hayat bilgisi ders kitaplarıyla ilgili yapılan çalışmalar daha az sayıda olduğu için incelenen ders kitapları da aynı oranda azdır. Sınıf öğretmenlerinde ise, genelde "51-100" sayı aralığında kişilerden ders kitaplarına yönelik görüş alındığı belirlenmiştir.

İncelenen makalelerin 32'si nitel ve 7'si nicel araştırma özelliği taşırken, 2'si literatür inceleme şeklindedir. Genellikle çalışmalarda ders kitapları doküman inceleme yöntemiyle analiz edildiğinden çalışmalar nitel yöntem özelliği taşımaktadır.

Veri toplama aracı doküman inceleme ilk sıradayken, bunu anket, görüşme, rubrik ve ölçekler takip etmektedir. Yine Güven ve Ayyayla-Püsküllü'nün (2017) çalışmasında da doküman inceleme ilk sırada yer almaktadır. İncelenen makalelerde veri analizi türü olarak içerik analizinin ilk sırada yer aldığı görülmektedir. Bunu "betimsel analiz, frekans ve yüzde hesaplama, varyans analizi ve $t$ testi" takip etmektedir. Yine bunun nedeni ise, nitel araştırmaya yönelik veri toplama araçlarının nicel veri toplama araçlarından daha çok yer almasıdır.

İncelenen çalışmalarda ders kitaplarının belirlenen bir konuya yönelik olarak değerlendirildiği tespit edilmiştir. Bu konular arasında, "genel ve özel becerileri kazandırma derecesine uygunluk, evrensel değerleri içerip içermedikleri, demokrasi uygulamaları için sınıf başkanı seçim konusu, örnek olayların sunumu, kurgusal metinlerin sunumu, öğrenme stratejilerinin kullanımı, toplumsal cinsiyet, aile, tüketici hakları ve çokkültürlü eğitime yer verilme düzeyleri, edebi ürünler ve biyografi kullanımı, coğrafya konularının belirlenmesi, insan hakları ve demokrasi kavramlarının belirlenmesi" yer almaktadır. Ders kitaplarının belirlenen bu şekilde konular çerçevesinde değerlendirilmesi, kitaplarda yer alan eksikliklerin tespit edilebilmesi bakımından önem taşımaktadır. Ayrıca çalışmalarda belirlenen konular doğrultusunda öğretmen görüşlerinin alınması da, çeşitli açılardan ders kitaplarının özelliklerine yönelik olarak, sürecin içinde yer alan öğretmenlerin fikirlerini belirtebilmeleri açısından oldukça önemlidir. Olumlu veya olumsuz olarak kitaplara yönelik öğretmenlerin görüş belirtmeleri, ileriki çalışmalar için bir ön bilgi niteliği taşıyabilmektedir.

Elde edilen tüm sonuçlar doğrultusunda ise, özellikle hayat bilgisi ders kitaplarıla ilgili çalışmaların sosyal bilgilere oranla daha az olduğu tespit edilmiş̧tir. Sınıf eğitimi alanındaki temel derslerden biri olduğu için hayat bilgisi eğitimi oldukça önem taşımaktadır. Bu nedenle bu derse yönelik ders kitaplarıyla ilgili çalışmaların arttırılması öneri olarak verilebilmektedir. Ayrıca bundan sonraki çalışmalarda, ders kitaplarıyla ilgili değişik yöntem ve tekniklerin yer aldığı makaleler taranarak bir meta-analiz çalışması yapılabilir. 


\section{KAYNAKÇA}

Akcan, P. İ. (2005). Edinim sürecinde görünüş ilköğretim 2. sınıf hayat bilgisi kitaplarındaki eylemler durum türleri ve görünüş etkileşimi. Ankara Üniversitesi Dil Dergisi, 130, 7-17.

Akman, Ö., \& Bastık, U. (2016). Sosyal bilgiler ders kitaplarında ihtilaflı konular içerisinde yer alan 'aile' kavramının incelenmesi: bir içerik analizi. Trakya Üniversitesi Eğitim Fakültesi Dergisi, 6(2), 247-263.

Aksoy, B., \& Sönmez, Ö. F. (2012). Sosyal bilgiler ders kitaplarındaki metin ve görsellerde harita becerileri. Atatürk Üniversitesi Edebiyat Fakültesi Sosyal Bilimler Dergisi, 12(48), 65-79.

Alaca, E. (2017). Sosyal bilgiler ders kitapları üzerine bir değerlendirme. 21. Yüzyılda Eğitim ve Toplum, 6(18), 759-785.

Aladağ, E., \& Karaman, B. (2018). A review of social studies coursebook in terms of thinking training: "science in time" unit. European Journal of Education Studies, 4(5), 235-255.

Alkış, S. (2005). İlköğretim birinci kademe sosyal bilgiler ders kitaplarında coğrafya konularıyla ilgili kavramların belirlenmesi (2004 programına göre). Marmara Coğrafya Dergisi, 11, 8392.

Alpan, G. B. (2004). Ders kitaplarındaki grafik tasarımının öğrenci başarısına ve derse iliş,kin tutumlarına etkisi. Eğitim Bilimleri ve Uygulama, 3(6), 193-209.

Aykac, N. (2012). Sosyal bilgiler ve hayat bilgisi ders kitaplarının toplumsal cinsiyet açısından değerlendirilmesi. Hacettepe Üniversitesi Eğitim Fakültesi Dergisi, 43, 50-61.

Baltacı, C., \& Uysal, M. T. (2012). Türkiye' de bir siyasal sosyalleşme aracı olarak ders materyali: ilköğretim sosyal bilgiler dersi üzerine bir inceleme. Süleyman Demirel Üniversitesi İktisadi ve İdari Bilimler Fakültesi Dergisi, 17(3), 177-194.

Berkant, H. G., \& Atmaca, Y. (2013). Altıncı ve yedinci sınıf sosyal bilgiler ders kitaplarının insan hakları ve demokrasi kavramları açısından incelenmesi, Turkish Studies, 8(12), 179-198.

Çoban, A., \& Temir, M. (2018). Türkiye' de sosyal bilgiler ders kitaplarında çevre eğitiminin yeri. Sosyal Bilimler Dergisi, 5(19), 21-34.

Doğan, Y., \& Tuğ, O. (2017). Uluslararası sinavlarda baș,arılı Türkiye'nin sosyal bilgiler ders tasarım boyutu açısından incelenmesi. Uluslararası Sosyal Bilgilerde Yeni Yaklaşımlar Dergisi, 1, 56-79.

Erol, B., \& Kıroğlu, K. (2012). Hayat bilgisi ders kitaplarının dil ve anlatım yönünden değerlendirilmesi. Selçuk Üniversitesi Türkiyat Araştırmaları Dergisi, 32.

Gezer, M., \& İlhan, M. (2015). Sosyal bilgiler dersi ögretim programı kazanımları ile ders kitabı değerlendirme sorularının solo taksonomisine göre incelenmesi. Sakarya Üniversitesi Eğitim Fakültesi Dergisi, 29, 1-25.

Gözütok, F. D., Taş, İ. D., Rüzgar, M. E., Akçatepe, A. G., \& Yetkiner, A. (2015). İlkokul birinci sınıf hayat bilgisi kitaplarının değerlendirilmesi. İlköğretim Online, 14(3), 825-844.

Gülersoy, A. E. (2013). İdeal ders kitabı arayışında sosyal bilgiler ders kitaplarının bazı özellikler açısından incelenmesi. International Journal of New Trends in Arts, Sports \& Science Education, 2(1), 8-26. 
Gülüm, K., \& Çeltik, D. (2014). İlkokul 2.sınıf hayat bilgisi ders ve çalışma kitabının niteliğini arttıracak öneriler. Cumhuriyet Üniversitesi Sosyal Bilimler Dergisi, 38(1), 46-58.

Güven, S. (2010). İlköğretim hayat bilgisi dersi ders ve öğrenci çalışma kitaplarının öğretmen görüşlerine göre değerlendirilmesi, Eğitim ve Bilim Dergisi, 35(156), 84-95.

Güven, S., \& Ayyayla-Püsküllü, M. (2017). Hayat bilgisi ders kitapları ile ilgili yapılan çalışmaların içerik analizi. The Journal of International Lingual, Social and Educational Sciences, 3(2), 75-86.

Güzel-Candan, D., \& Ergen, D. (2014). 3. sınıf hayat bilgisi ders kitaplarının temel evrensel değerleri içermesi bakımından incelenmesi. Uşak Üniversitesi Sosyal Bilimler Dergisi, 7(1), 134-161.

İncekara, S., \& Karatepe, A. (2010). Sosyal bilgiler öğretmenlerinin yeni program temelinde ders kitaplarına yönelik düşünceleri, Marmara Coğrafya Dergisi, 21, 46-64.

Kabapınar, Y. (2002). İlköğretim hayat bilgisi ve sosyal bilgiler öğretiminde kullanılan ders kitapları ve öğretim materyalleri açısından Türkiye ve İngiltere örnekleri. Kuram ve Uygulamada Ĕ̈itim Bilimleri, 2(1), 247-270.

Kabapınar, Y. (2007). 1998 ve 2004 ögretim programlarına göre yazılmıs hayat bilgisi ve sosyal bilgiler ders kitaplarında sosyal olay ve degerlerin sunumu. Eğitim Bilimleri Dergisi, 25(25), 109-127.

Kabapınar, Y., \& Akbal, Y. (2010). Sınıf ögretmenlerinin 1998 ve 2004 yılı ilkögretim programlarına göre hazırlanmış hayat bilgisi ders kitaplarına iliş̧in değerlendirmeleri. Marmara Üniversitesi, Atatürk Eğitim Fakültesi Eğitim Bilimleri Dergisi, 32(32), 95-122.

Kabapınar, Y., \& Özkan, Ö. (2012). Hayatın bilgisine ilişkin deneyimler sunma boyutunda hayat bilgisi ders kitaplarındaki örnek olaylar ve işlevleri. Marmara Üniversitesi Atatürk Eğitim Fakültesi Eğitim Bilimleri Dergisi, 35(35), 137-156.

Karabacak B., \& Turan, İ. (2007). İlköğretim birinci kademe sosyal bilgiler ders kitaplarının sınıf öğretmenliği öğretmen adaylarına göre bir degerlendirmesi. Atatürk Üniversitesi Kazım Karabekir Ĕ̆itim Fakültesi Dergisi, 16, 209-233.

Karaca, N. H., \& Ocak, G. (2011). Hayat bilgisi ders kitaplarının becerilere uygunluk düzeyinin öğretmen görüşlerine göre değerlendirilmesi (Afyonkarahisar ili örneklemi). Kuramsal Ĕ̆itimbilim, 4(1), 108-125.

Karaman-Kepenekci, Y., \& Ökdem, M. (2013). İlköğretim hayat bilgisi ve sosyal bilgiler ders kitaplarında tüketici hakları. İlkö̆retim Online, 12(3), 674-686.

Kaya, B., Topçu, E., \& Kop, Y. (2014). 7. sınıf sosyal bilgiler çalışma kitaplarının yapılandırmacı öğrenme yaklaşımı açısından incelenmesi, Turkish Studies, 9(5), 1327-1340.

Kaymakc1, S., \& Er, H. (2013). Sosyal bilgiler öğretim programı ve ders kitaplarında biyografinin kullanımı. Mehmet Akif Ersoy Üniversitesi Eğitim Fakültesi Dergisi, 13(25), 198-224.

Keskin, Y., \& Yaman, E. (2014). İlköğretim sosyal bilgiler program ve ders kitaplarında yeni bir paradigma: çokkültürlü eğitim. Turkish Studies, 9(2), 933-960.

Mentiş-Taş, A. (2007). Yenıi sosyal bilgier ders kuitaplarına ilişkin öğretmen görüşlerinin belirlenmesi. Selçuk Üniversitesi Sosyal Bilimler Enstitüsü Dergisi, 17, 519-532. 
Milli Eğitim Bakanlığı. (2018). İlkokul hayat bilgisi dersi 1, 2 ve 3. sınıflar öğretim programı. Ankara: Milli Eğitim Bakanlığı Yayınları.

Nalçac1, A. (2011). İlkögretim 5. sınıf sosyal bilgiler ders kitabının ögretmen görüşlerine göre değerlendirilmesi (Erzurum örneği). Atatürk Üniversitesi Sosyal Bilimler Enstitüsü Dergisi, 15(2), 321-335.

Öztürk, İ. H. (2011). Tarih öğretiminde anakronizm sorunu: sosyal bilgiler ve tarih ders kitaplarındaki kurgusal metinler üzerine bir inceleme. Sosyal Bilgiler Egĭtimi Araș,trmalar Dergisi, 2(1), 37-58.

Öztürk, T., \& Özkan, Z. S. (2018). Hayat bilgisi ders kitaplarındaki metin ve görsellerin değerler açısından incelenmesi, Eğitimde Nitel Araştırmalar Dergisi, 6(1), 172-204.

Pamuk, İ., \& Pamuk, A. (2016). Almanya'da sachunterricht ve Türkiye'de hayat bilgisi ders kitaplarında okulda demokrasi uygulamalarına örnek olarak sınıf başkanı seçimi. Cumhuriyet International Journal of Education, 5(2), 67-83.

Sever, R., \& Koçoğlu, E. (2013). Sosyal bilgiler ders kitaplarındaki coğrafya konularına ilişkin sosyal bilgiler öğretmenlerinin görüşleri/ Diyarbakır merkez ilçe örneği. Elektronik Sosyal Bilimler Dergisi, 12(45), 17-34.

Şahin, M. (2012). Ders kitaplarının mesaj tasarımı ilkeri açısından değerlendirilmesi. Ahi Evran Üniversitesi Kırşehir Eğitim Fakültesi Dergisi (KEFAD), 13(3), 129-154.

Tay, B. (2005). Sosyal bilgiler ders kitaplarında öğrenme stratejileri. Gazi Üniversitesi Kırşehir Eğitim Fakültesi Dergisi, 6(1), 209-225.

Tel, M. (2014). İlköğretim hayat bilgisi ders kitaplarındaki spor ve boş zaman temalarının değerlendirilmesi. Akademik Sosyal Araştırmalar Dergisi, 2(2), 1-11.

Tural, A., Şahan, G., Işık, A. D., Özdemir, S., Uysal, H., \& Yılmaz, O. (2017). Türkiye ve Almanya'daki hayat bilgisi ders kitaplarının resim-metin ilişkileri ve kullanımları bakımından karşılaştırılması, Bartın Üniversitesi Eğitim Fakültesi Dergisi, 6(2), 770-782.

Ünal, Ç., \& Ilgaz, S. (2005). I. kademe ilköğretim sosyal bilgiler ders kitaplarındaki coğrafya konularının öğrencilerin soru sorma ve eleştiri yapma becerilerine olan katkısı (Erzurum İl Merkezi Örneği). Atatürk Üniversitesi Sosyal Bilimler Enstitüsü Dergisi, 6(2), 129-139.

Ünal, F., \& Ünal, M. (2012). Sosyal bilgiler öğretim programları (1924-2005) ve ders kitaplarında (2005-2010) harita okuma becerisi, Milli Ĕ̆itim, 193, 165-183.

Yıldırım, A., \& Şimşek, H. (2013). Sosyal bilimlerde nitel araştırma yöntemleri. Ankara: Seçkin Yayınevi.

Yurdugül, H. (2005). Ölçek geliştirme çalışmalarında kapsam geçerliği için kapsam geçerlik indekslerinin kullanılması. XIV. Ulusal Egĭtim Bilimleri Kongresi (s.1-6). Denizli: Pamukkale Üniversitesi. 